\title{
Groundwater Regulation and Integrated Water Planning
}

\author{
Philippe Quevauviller, Okke Batelaan, and Randall J. Hunt
}

\begin{abstract}
The complex nature of groundwater and the diversity of uses and environmental interactions call for emerging groundwater problems to be addressed through integrated management and planning approaches. Planning requires different levels of integration dealing with: the hydrologic cycle (the physical process) including the temporal dimension; river basins and aquifers (spatial integration); socioeconomic considerations at regional, national and international levels; and scientific knowledge. The great natural variation in groundwater conditions obviously affects planning needs and options as well as perceptions from highly localised to regionally-based approaches. The scale at which planning is done therefore needs to be carefully evaluated against available policy choices and options in each particular setting. A solid planning approach is based on River Basin Management Planning (RBMP), which covers: (1) objectives that management planning are designed to address; (2) the way various types of measures fit into the overall management planning; and (3) the criteria against which the success or failure of specific strategies or interventions can be evaluated (e.g. compliance with environmental quality standards). A management planning framework is to be conceived as a "living" or iterated document that can be updated, refined and if necessary changed as information and experience are
\end{abstract}

P. Quevauviller $(\bowtie)$

vrije universiteit, Brussel (VUB), Belgium

e-mail: Philippe.Quevauviller@ec.europa.eu

O. Batelaan

Strategic Professor Hydro(geo)logy, School of the Environment, Flinders University, GPO Box 2100, Adelaide, SA 5001, Australia

e-mail: okke.batelaan@flinders.edu.au

R.J. Hunt

United States Geological Survey, 8505 Research Lane, Middleton, WI 53562, USA

e-mail: rjhunt@usgs.gov 
gained. This chapter discusses these aspects, providing an insight into European Union (EU), United States and Australia groundwater planning practices.

\subsection{Introduction}

The complex nature of groundwater calls for emerging groundwater problems to be addressed through integrated management approaches designed to change the way people view and use the resource. Three levels of integration are concerned: (1) within the hydrologic cycle (the physical process) including the temporal dimension; (2) across river basins and aquifers (spatial integration); and (3) across socioeconomic sectors at regional, national and international levels (Mostert et al. 1999). A fourth level of integration concerns the way scientific knowledge is used (Quevauviller 2008). The great range of the natural variability inherent to groundwater systems obviously affects management needs and options, i.e. from highly local management approaches to regionally-based approaches. The management scale hence requires an encompassing evaluation of available policy choices and options for each particular setting. This is more complex than for example, river basin management delineated using land surface, owing to a three-dimensional structure of the aquifer systems with often unknown and unmapped boundaries, and complex temporal responses (e.g. lags) of aquifer systems. General principles of integrated water-resource management, address groundwater management in the context of a strategic framework that encompasses these and other characteristics. This chapter provides an insight into integrated groundwater planning, with examples taken from the European Union Water Framework Directive (WFD-http://ec.europa.eu/environment/water/waterframework/index_en.html) River Basin Management Planning (RBMP) as well as groundwater regulations in effect in Australia and USA.

\subsection{Challenges Linked to Groundwater Management}

Fully integrated approaches for groundwater management may precipitate massive data collection and planning efforts, which, given the potential large size and scope, may be out of date before they are completed. As a result, the level of integration must be balanced against practical limitations and the often superior effectiveness of immediate action to address developing problems. Whole-system perspectives and adaptive management approaches are generally considered to be more practical than the ideal "fully integrated" approaches. Both approaches require a strong conceptual understanding of the natural groundwater conditions while also encompassing a broad array of physical, social, economic and institutional factors affecting water management needs and options. Institutions are often required to be knowledgedriven with broad access to data and information, and need personnel capable of articulating a broad interdisciplinary understanding of water management issues.

Therefore there is a need for flexibility in groundwater management. Because social, economic and hydrological systems are dynamic rather than static, and 
factors directly or indirectly affecting groundwater conditions vary greatly from place to place, integrated groundwater management is not amenable to a one-sizefits-all approach. This implies the development of a management framework that acknowledges social, economic and physical resource conditions important in different management areas (Burke and Moench 2000). National frameworks that attempt to specify smaller scale management details (e.g. spacing of wells, specific prices for water) will often enumerate actions that are inappropriate or unworkable at the local or even regional level. In contrast, national frameworks that focus on broad principles and provide clear administrative and/or legal guidance enable local or regional managers to flexibly tailor more workable and efficient solutions. This also facilitates effective participatory planning involving scientists, resource management specialists, stakeholders, and decision-makers.

Groundwater management complexity tends to increase with increasing spatial and temporal scale, which in turn encompasses a wider range of conditions in the groundwater system. Therefore, management activities carried out at the smallest scale and at the lowest administrative level (at which they can effectively be carried out) are easier and most effective to tackle. This tenet needs to be balanced against management decisions related to the large and connected nature of groundwater systems - connections that propagate local management activities into the larger system. That is, institutional views of recognizing and accounting for resource management areas reflect the physical scale at which groundwater systems function and, in this respect, clear management units are as important for the development of effective management institutions as they are for scientific understanding (e.g. river basin or "water body" as defined in the EU Water Framework Directive, see Sect. 8.9). Therefore, local management actions have to reflect wholesale aquifer dynamics and fit within a management framework that recognizes the aquifer as the primary unit for management of the resource. The challenge is to manage large aquifer systems with a single overarching scientific framework and clear objectives that will facilitate overall aquifer management and ensuring that local approaches are consistent with the overarching framework.

\subsection{Integrated Water Management Framework}

\subsubsection{Water and Its Environment}

The surface-watershed constitutes the basis of river basin management (RBM) in the framework of which groundwater may be managed in an integrated way. Although the groundwater and surface-water divide may not exactly align (e.g., Hunt et al. 1998; Winter et al. 2003), the system can be defined for management as the geographical area determined by the surface-watershed limits of the system of waters, including surface water and groundwater. Strong interactions usually exist between groundwater and surface water in the basin, between water quantity and quality, and between land and water, upstream and downstream. This means that hydrologic basins can be managed not only as a geographical area but as a coherent 
social and ecological system (Burke and Moench 2000). Such entities are considered open systems in that these systems interact continuously with the atmosphere (precipitation and evaporation, airborne pollution) and terminal receiving waters (e.g., wetlands, lakes, oceans).

Waters within these systems fulfill many important functions, such as water supply for households, industry and agriculture, navigation, fishing, recreation and ecological niches. Economic and social development and even life itself cannot be sustained without sufficient water at the right time and place and of sufficient quality. In addition, water has shaped and continues to shape the environment, eroding mountain areas, creating karst, transporting sediment and creating delta areas. It is an essential element of nature while being subject to variability caused by human activities or natural causes, e.g. climate change, which can lead to floods or droughts. Effective RBM has to tackle all these issues, i.e. RBM is much broader than traditional water management as it includes land-use planning, policy (e.g. agricultural) and integrated management principles for groundwater. It also covers all human activities that use or affect surface water and groundwater systems.

\subsubsection{River Basin Management Objectives}

River basin management (RBM) principles aim at ensuring the multifunctional use of waters in rivers and their basins for the present and future generations. Since the capacity of river basins to accommodate different uses is always limited, with effective management, priorities have to be set. In particular, basic human needs have to be safeguarded (i.e. water supply for drinking and basic hygiene) and environmental protection should be given a full place in RBM. Apart from that, other priorities depend on the natural, social and economic conditions in the particular basin. Four different management levels can be distinguished according to Mostert et al. (1999): operational management, the institutional framework, planning and analytical support. Only operational management affects river basins directly. The following sections provide more details about these four components and issues relating to transboundary aquifer management and public participation.

RBM is closely linked to decentralization, i.e. government authorities are brought as close as possible to individual citizens, allowing for local variation in response to local circumstances and preferences for the notion of "subsidiarity" (a principle that is fully embedded into the EU Treaty). This is also more efficient as decentralized government tends to be less bureaucratic - simply because of its size - and better informed about local circumstances. Decentralization is not possible, however, for tasks such as establishing the institutional structure and formulating policies that apply to a large region or Nation as a whole. However, decentralized governments should be involved with RBM because of their superior information on local conditions and because of their (usually) closer contacts with the population within the river basin. Decentralization may also not be possible if the decentralized governments lack the necessary management capacity. Solutions could include local capacity building and advisory services by specialized central governments. 


\subsection{Operational Management}

Operational management embeds activities such as river regulation, constructing and operating water-supply infrastructure, reforestation projects, aquifer artificial recharge, etc. Operational management is linked to legal and policy requirements and guidelines and related measures. These may include emission controls of agricultural or industrial pollutants, abstraction controls, codes of good practices (e.g. Best Available Technologies, Best Environmental Practices, Best Management Practices), construction and/or rehabilitation projects and desalination plants. RBM may also address the behavior of different users/managers by explicitly forbidding, regulating or allowing certain activities (legislative or administrative instruments) in the basin and by offering economic (dis)incentives (economic or fiscal instruments) for some of these activities. Different resources are necessary to apply these instruments, such as financial, personnel, legal, appropriate policy directives and data.

\subsubsection{Pollution Control}

In a sustainable world, pollution control would be limited, i.e. emissions of contaminants of concern to the river basin would be close to zero. The main issue is how to approach this target and solve urgent pollution problems while ensuring that further pollution risks are prevented or limited. Regulations hence generally focus on programs for preventing or limiting inputs of pollutants into waters of the basin, e.g. control of point and diffuse sources of pollution through a combined approach based on emission controls using best available techniques, relevant emission values or best environmental practices (in the case of diffuse pollution) which are set out in relevant legislation (dealing with industrial, urban or agricultural sources of pollution). This may be complemented by a water-quality approach based on the establishment and compliance to water-quality standards, and the requirement to identify and reverse any statistically and environmentally significant pollution trends. There is no universally best approach, i.e. each situation may require tailor-made solutions which will be designed according to factors such as the urgency of pollution problems, the substance concerned, the pollution source and the capacity of the managers. In practice, the different approaches are often combined, e.g. minimum uniform emission standards combined with more stringent pollution controls if the water quality so requires.

\subsubsection{Voluntary Agreements}

Enforcement is a great concern in all regulatory instruments. Personnel and equipment are often insufficient for frequent monitoring, sometimes the different bodies responsible for enforcement may not co-operate effectively and political forces and lobbying may prevent strict sanctioning. Voluntary agreements and other 
communicative instruments may offer a partial solution, in particular with regard to agricultural activities. They are based on the co-operation of the (ground) water users or polluters: the latter are not forced but persuaded to do (or not to do) something. In this context, users and polluters may be willing to agree on quite ambitious goals, which may go beyond traditional regulatory incentives. This concerns not only groundwater regulations but also parent regulations (e.g. agriculture-related policies) directives which have to be effectively implemented to ensure a proper groundwater management planning.

\subsubsection{Cost Recovery}

Another operational issue is related to recovery of costs of water services, which takes into account that the polluter pays principle. It may require (like in the EU) authorities to establish water pricing policies, fixing adequate contributions of the different water uses, disaggregated into industry, households and agriculture. This policy depends on the price elasticity (the sensitivity of water use/pollution to the costs of the user/polluter), which is generally low in the case of drinking water use and high in the case of irrigated agriculture (the major water user in many countries). Charges that reflect the full economic and environmental costs of water use and pollution are economically efficient since they confront the water user/polluter with the real costs and promote an integral assessment of the costs and benefits. Moreover, they solve the financing problems of the providers of the water service concerned. However, this principle has to consider social, environmental and economic effects, as well as geographic and climatic conditions of the region or regions affected. In many instances, the cost recovery principle is not fully operational. An alternative approach is to fund particular preventive or remedial measures. This approach may be used, for example, if water becomes too expensive for poor populations. Indeed, very high charges and especially rapid increases may decrease the willingness to pay and may result in massive political opposition.

\subsubsection{Institutional Structure}

Mostert et al. (1999) illustrate different instruments for operational management that are applied in an institutional structure which consists of formal and informal working rules. Operational rules provide a framework for operational management, e.g. emission standards and (groundwater) policies. Collective choice rules deal with how operational rules should be developed, e.g. permitting and planning procedures. Constitutional rules determine who is entitled to make collective choice rules, setting up the organizational structure for RBM and allocate tasks and competencies (e.g. river basin district authorities). In this context, three basic RBM models are distinguished: 
- The hydrological model in which the organizational structure for water management is based on hydrological boundaries. In its extreme form all water management is in the hands of a single entity: the "river basin authority".

- The administrative model is in many respects the opposite of the hydrological model. In this model water management is the responsibility of provinces, municipalities and other bodies not based on hydrological boundaries.

- The coordinated model falls somewhere between the hydrological and the administrative model. In this model water management is not performed by river basin authorities, but public agencies, public coordination bodies or publicprivate partnerships or private river basin organisations coordinate river basin management.

Each model has advantages and disadvantages. In the hydrological model, administrative procedures coincide with hydrological boundaries, which limit the risk of upstream-downstream conflicts. However, since river basin authorities usually deal with water management only, this model may isolate water management from other relevant policy sectors, and inter-sectorial coordination may become a problem. In the administrative model water management, land-use planning and other relevant policy sectors can be kept together (but not necessarily). A major disadvantage is the serious risk of upstream-downstream conflicts and the lack of a platform to discuss these problems. Finally, an example of coordinated model is illustrated by river basin commissions (e.g. the International Commission for the Protection of the Danube River). The different bodies participating in these commissions may individually ensure co-ordination between water management and other policy sectors, and together, in the commission, they may coordinate their water management.

\subsection{Planning}

Whereas operational RBM constitutes the functional core of RBM, planning linked to policies has an important supportive role to play. As important as the plans and policies themselves is the way in which they are prepared: the "planning process" is a means to improve and support operational management.

\subsubsection{Functions of Plans and Policies}

Plans and policies can support operational RBM in several ways. Firstly, planning helps to assess the present situation in the basin, starting by an analysis of pressures and impacts and economic considerations, and measures required to meet predefined targets (e.g. quality and quantity objectives). It helps to orient operational management and set priorities. Secondly, it is impossible in practice to carry out policy analysis and organize public participation for each individual operational decision, and planning may provide the necessary framework. Thirdly, open and 
participatory planning processes may result in more public support or acceptance of the resulting plan/policy and (by extension) operational management. Fourthly, plans and planning may have a coordinating effect, i.e. bringing different river basin managers into discussion with each other with resulting plans and policies acting as common focal points.

\subsubsection{The Planning Process}

Planning requires extensive technical and scientific information, preparatory work and negotiation, considering different steps as described by Mostert et al. (1999):

1. Identification of planning needs, possibly involving some preliminary research;

2. Analysis of the institutional RBM framework and identification of the different operational decisions that can be taken, the bodies responsible for these decisions and their management capacity;

3. Identification of all the possible other stakeholders and their main interests;

4. Preparation of a process design, describing the scope of the planning exercise; the different phases; the different groups to be involved in each phase and the means to do so; the necessary research in each phase; and the project organization;

5. Implementation of the process design, resulting in the adoption of a plan; and

6. Implementation of the plan.

After a while, the plan and its implementation can be evaluated, and the process can start again. This form of planning cycle with review taking into account scientific progress is in force within the EU Water Framework Directive (see Sect. 8.9).

\subsubsection{Planning Systems}

Plans and policies relevant to RBM can differ on many dimensions-policy sectors, geographical scope, available funding, etc.- - which differ from country to country and from basin to basin. General guidelines may however be given, e.g. river basin planning should consider different interrelations within water systems (surface water and groundwater quantity and quality), the basin characteristics and their socioeconomic environment. This does not mean that each individual plan should have such a broad scope. Rather, the thinking should be in terms of planning systems: sets of interrelated types of planning, consisting of strategic and operational plans (e.g. linked to different regulatory frameworks concerning industrial, urban or agricultural activities). The more strategic a plan is, the more important it is that it covers complete river basins and all relevant policy sectors. Operational plans go more into detail and usually cover only one policy sector or part of a sector. 
The types of plans will depend on specific features, e.g. if in a specific basin there is one very urgent, very obvious issue, such as pollution of drinking water sources, there may be no need for integrated strategic planning that provides a complete integrated description of the basin and sets long-term goals. The resources could be much better used for making and implementing an operational plan that sets specific and concrete targets, proposes operational measures, and creates the necessary support linked to the specific feature.

Generally speaking, plans should be designed, taking into consideration the management capacity of the countries and basins. The number and scope of plans may be constrained by the amount of resources available for each planning exercise. Coordination between the plans can become problematic and transparency for the citizen is reduced. Moreover, resources that are spent on planning cannot be spent on operational management.

\subsection{Analytical Support}

River basin management is a complex task. Therefore, tools helping to assess the present situation and assist the development and evaluation of solutions are important. Two types of support may be distinguished: (1) support to operational management (e.g. action programs) and (2) support to strategic policy-making and planning (e.g. RBPM cycles). A second distinction is between (support) systems for monitoring, data collection and processing, oriented towards making facts and figures about the present situation and about possible trends; and tools or systems to support decision-making with a view to the future, typically oriented to the ex ante identification, analysis and evaluation of alternative allocations, policies or plans. These distinctions are not absolute. Operational management and strategic policymaking interact, and data collection and ex ante analysis support each other.

The development of information and computer technology over the last 30 years has enabled the design and application of a wide array of systems and modeling tools for supporting water managers. Most efforts in the field have so far concentrated on the technical and physical aspects of the (physical) river systems itself, and little attention has been paid to the development of systems and tools covering relevant aspects and processes in the river basin as a whole. This can be partly explained by the complexity of monitoring and analyzing of the interaction between natural and socioeconomic systems at the scale of a river basin, which are informed by on-going research trends and development of multidisciplinary synergies.

\subsubsection{Analytical Support for Operational Management: Main Challenges}

Many analytical tools have become available to support operational management. With respect to groundwater, efforts are still required to harmonize monitoring and 
analysis methods used by different organizations, especially in the case of international basins. A second challenge is to make the information available to anybody involved or interested. The development in database technology, often in combination with internet applications, can provide powerful tools for data retrieval and map visualization.

A more advanced type of operational support is to combine on-line monitoring with computer models in order to predict future conditions of the system. Examples are early warning systems, both for water-quantity issues (floods, droughts) and for water-quality issues (accidental spills). Flood early warning systems are already installed in many major basins in the world. An even more advanced form of support is the automation of infrastructure operation, such as weirs, pumps and sluices. In most cases such tools do not replace human operators: they provide the necessary information, but the decision is left to operators. This information is generated using monitoring data, often combined with computer models that describe the behavior of the natural system (water levels, discharges, etc.). The main challenge is to develop support systems that describe not only the natural system but also the use functions related to this system, thus enabling a weighing of all aspects involved.

\subsubsection{Analytical Support and the Strategic Level: New Directions}

At the level of strategic planning and policy-making, efforts so far are mainly related to the development of specific tools for specific problems in specific river basins, e.g. options for managing and cleaning up heavy metal pollution in a given groundwater body. Challenges for developing more generic and comprehensive tools at the river basin level are enormous as there is a lack of data and theories that may fully describe complex processes taking place in a groundwater body or groups of groundwater bodies within a river basin, taking socioeconomic issues into consideration. This does not allow one to include all relevant issues in a single model or tool. Yet, given the crucial importance and complexity of management at the basin level, it is of utmost importance that investments are made in the further development of analytical approaches and associated tools. Some possible tool development orientations are highlighted by Mostert et al. (1999):

- Tools for supporting integrated management and analyses at the river basin level describing not only the different aspects (quantity and quality) of the physical system, but also interactions with the socioeconomic system;

- Tools facilitating the linkage of (aggregated) strategies at the basin level and strategies at the regional and local levels to take account of processes and implementation aspects that have a regional rather than a basin-wide character. The challenge is to develop a family of tools operating at different geographical scales and levels of aggregation, linked to each other for overall consistency;

- Tools or models describing the costs and benefits of specific actions to the various actors involved, also helping to explore the possibilities for exchanges 
between actors, to assess the need to involve other actors in the process and possibly to identify potential linkages to other issues that would turn in a winlose situation into a win-win situation. Analysis of cost and benefits need to take account of recent developments in the estimation of unpriced values, especially environmental valuation;

- Support systems and tools that are better tuned to the dynamic and increasingly participatory nature of policy processes, i.e. accessible to non-specialists. For interactive learning settings there is a need for more flexible and transparent tools;

- Alternatives to the traditional tools based on "objective" system analytical approaches should be explored, e.g. striving to distinguish between "objective" knowledge and subjective judgments. Perceptions of problems and solutions are inevitably affected by differences in interests of participants, and arguments put forward in policy debates typically contain a mixture of "objective" facts and subjective viewpoints or perceptions. Argumentation analysis may be supported by tools specifically designed to describe, visualize and analyze policy arguments;

- Another novel approach is to use gaming as a vehicle for learning. In a policy game, participants interact as if they were playing the role of different parties involved in a real-world issue. Such games can be very instructive to both participants and observers as they include parts of the social and psychological dynamics of real policy processes, which cannot be included in more traditional systems. Policy games are generally supported by computer-based tools that take account of physical and other aspects in the process;

- New opportunities linked to developments of information and communication technology, e.g. geographical information systems (GIS) and interactive interfaces, allowing use of support tools by a broader group of users, and the development of the internet.

\subsection{Internationally Shared Aquifers}

A special management feature concerns internationally-shared aquifers. Natural and socioeconomic conditions, culture and language often differ significantly between different parts of the region where the aquifer is located, and consequently upstream-downstream conflicts may occur. More importantly, however, internationally shared aquifers are by definition located in different states. Consequently, international co-operation is needed in order to best manage the aquifer resources. This co-operation can be made more effective when required by law. In this respect, a major problem in the management of international basins is the so-called "lowest common denominator": Few obligations can be imposed on countries without their own consent in the absence of an international regulatory framework imposing coordination towards the achievement of common objectives. In the absence of such international law, many international agreements simply reflect the 
commonalities in the national policies of the states concerned or are very procedural and vague.

At the global level the normative system for the management of internationally shared aquifers focuses on the discretion of states and their sovereignty, rather than on their particular responsibilities in the process towards attaining sustainable water management, even if cooperation among those states is encouraged in conformity with existing agreements. Compliance regimes have now been included or are being developed in most multilateral environmental agreements, e.g. a procedure that entails that, at the request of a state, the commission coordinates negotiations among the parties and makes recommendations for an equitable solution to the dispute. While these recommendations are not binding in law, the parties to the dispute are to consider them in good faith. Such a procedure remains short of the compliance regimes included in multilateral environmental agreements in that it does not provide an automatic peer review system. It may, however, provide a mechanism through which the normative content of the international regime for groundwater management may be enhanced.

\subsection{Public Participation}

Public participation plays an essential role in planning and policy-making. It can be seen as a legal right of individuals and social groups, often resulting in procedural requirements for decision-making. Public participation can also be seen as a means for empowering individuals and groups and developing local communities. Furthermore it can be seen as a means of improving the quality and effectiveness of decision-making (REF). Public participation as a legal right is based on the notion that individuals and groups affected by decisions should have the opportunity to express their views and become involved in decision-making. Often three "pillars" of public participation are identified: access to information, involvement in the decision-making process (e.g. possibility to comment), and access to justice (right of legal review and redress). The danger of a purely legal approach to public participation is that it may become nothing more than an administrative requirement. Moreover, litigation is often time-consuming and expensive.

With regard to groundwater management, four groups stand out and should, as a basic principle, be involved in management initiatives:

- local stakeholders - water users and others whose interests are directly affected by groundwater management and whose actions often determine the effectiveness of any given initiative;

- policy-makers - those who have the ability to influence the institutional environment within which management approaches must evolve;

- public-sector organisations - these stakeholders often have their own internal agendas and control large programmes that either directly or indirectly have major impacts on water resources; and 
- private-sector organisations - these stakeholders are often major water users whose interests may or may not coincide with those of local stakeholders.

Stakeholder involvement and education are essential for any attempt to manage groundwater resources. It cannot, however, concern each individual but rather groups representing communities which may have a major impact on the resource (e.g. large water users such as municipalities, agricultural sector) and those whose interests will be significantly affected by management regimes (these groups are not mutually exclusive). The principle of stakeholder involvement is to start by being as inclusive as possible. The involvement and education will be all the more efficient if it is linked to a legal base, thus mixing stakeholder organisations with policy makers guiding discussions in relation to policy development, implementation and review needs.

\subsection{The EU Approach}

Groundwater planning within the EU regulatory context derives directly from the components of the Water Framework Directive, covering the following steps:

- Definition and characterisation of groundwater bodies (management units) within well-defined River Basin District which had to be carried out in the years 2004-2005. This involved an analysis of the pressures and impacts of human activity on the quality of groundwater with a view to identifying groundwater bodies at risk of not achieving WFD environmental objectives (of "good status", see below). This assessment has to evaluate risks linked to water uses and interactions with associated aquatic or terrestrial ecosystems in relation to the types of pressures and aquifer vulnerability;

- Establishment of registers of protected areas within each river basin district, which have been designated as requiring specific protection of their surface and ground waters or for the conservation of habitats and species directly dependent on water;

- Design and establishment of groundwater monitoring networks based on the results of characterisation and risk assessment to provide a comprehensive overview of groundwater chemical and quantitative status (this had to be done by EU Member States by the end of 2006). In this context, data monitoring constitutes an essential element of the overall management cycle;

- Development of river basin management plan (RBMP) for each river basin district, including a summary of pressures and impacts of human activity on groundwater status, a presentation in map form of monitoring results, a summary of the economic analysis of water use, as well as the implementation of the principle of recovery of costs for water services, including environmental and resource costs in accordance with the polluter pays principle, a summary of protection programmes, and control and remediation measures. The first RBPM 
has been published in December 2009. A review is then planned by the end of 2015 and every 6 years thereafter;

- Development and implementation of a programme of measures for achieving WFD environmental objectives (e.g. abstraction control, prevent or control pollution measures) operational since 2012. Basic measures include, in particular, controls of groundwater abstraction, controls (with prior authorisation) of artificial recharge or expansion of groundwater bodies (providing that it does not compromise the achievement of environmental objectives, meaning that the reuse of e.g. treated wastewater should not lead to a deterioration of the quality of receiving ground waters). Point source discharges and diffuse sources liable to cause pollution are also regulated under basic measures which are in force in other directives e.g. agriculture-related directives (Nitrates, Plant Protection Products), urban-related directives (Urban Wastewater Treatment) or chemical industry-related directives (Integrated Pollution Prevention and Control). Direct discharges of pollutants into groundwater are prohibited subject to a range of provisions listed in Article 11 of the WFD. The programme of measures has to be reviewed and if necessary updated by 2015 and every 6 years thereafter.

The Groundwater Directive (GWD) complements the above WFD components in establishing a regime which sets underground water quality standards and introduces measures to prevent or limit inputs of pollutants into groundwater (European Commission 2006). The directive establishes quality criteria that take into account local characteristics and allows for further improvements to be made based on monitoring data and new scientific knowledge. It thus represents a proportionate and scientifically sound response to the requirements of the Water Framework Directive (WFD) as it relates to assessments on chemical status of groundwater and the identification and reversal of significant and sustained upward trends in pollutant concentrations. In this context, EU Member States had to establish the standards (threshold values) at the most appropriate level, taking into account local or regional conditions. Complementing the WFD, the Groundwater Directive includes the following obligations:

- groundwater threshold values (quality standards) had to be established by Member States by the end of 2008 and revised on a regular basis in the light of scientific knowledge;

- pollution trend studies should be carried out using existing data and monitoring data which are mandatory under the WFD (referred to as "baseline level" data obtained in 2007-2008);

- pollution trends should be reversed so that environmental objectives are achieved by 2015 using the measures set out in the WFD (corresponding to a series of parent legislation setting legal rules for agricultural, domestic and industrial pollution risks and management);

- measures to prevent or limit inputs of pollutants into groundwater should be operational so that WFD environmental objectives can be achieved by 2015 ; 


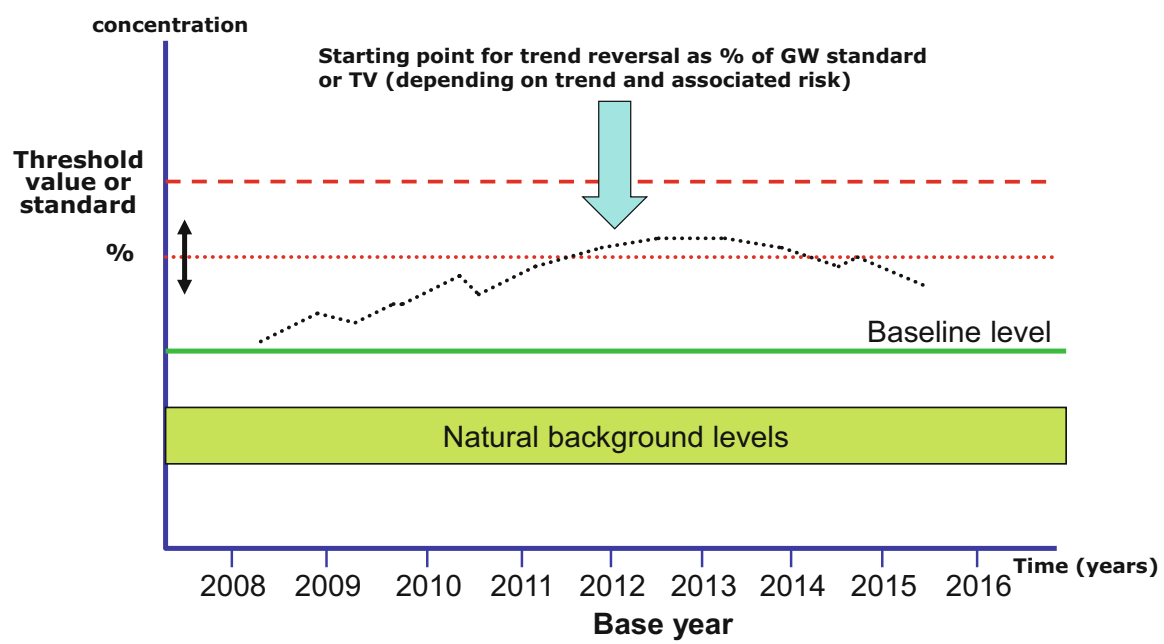

Fig. 8.1 Principle of the identification and reversal of statistically and environmentally significant upward trends. The 'Baseline Level' corresponds to the average value measured at least during the reference years 2007 and 2008 on the basis of monitoring programmes of the WFD, while the 'Background Level' means the concentration of a substance of the value of an indicator in groundwater corresponding to no, or only very minor, anthropogenic alterations to undisturbed conditions. TV stands for 'Threshold Values'

- compliance with good chemical status criteria (based on EU standards of nitrates and pesticides and on threshold values established by Member States) should be achieved by the end of 2015 .

The good chemical status achievement is based on quality objectives (compliance to relevant standards either EU-based or established by the Member States, no saline intrusion) that have to be achieved by the end of 2015 . The identification of sustained upward pollution trends and their reversal implies that trends will have to be identified for any pollutants characterising groundwater as being at risk (this is linked to the analysis of pressures and impacts carried out under the WFD). The reversal obligation establishes that any significant and sustained upward trend will in principle have to be reversed when reaching $75 \%$ of the values of EU-wide groundwater quality standards and/or threshold values (Fig. 8.1) through the programme of measures of the WFD where the parent legislations are the implementation tools for ensuring effective actions (e.g. Nitrates Directive, IPPC Directive, etc.).

Finally, measures to prevent or limit the introduction of pollutants into groundwater are related to the level of risks of different types of substances (some to be prevented, others to be limited). The principles are linked to conceptual modelling needs (Fig. 8.2). 


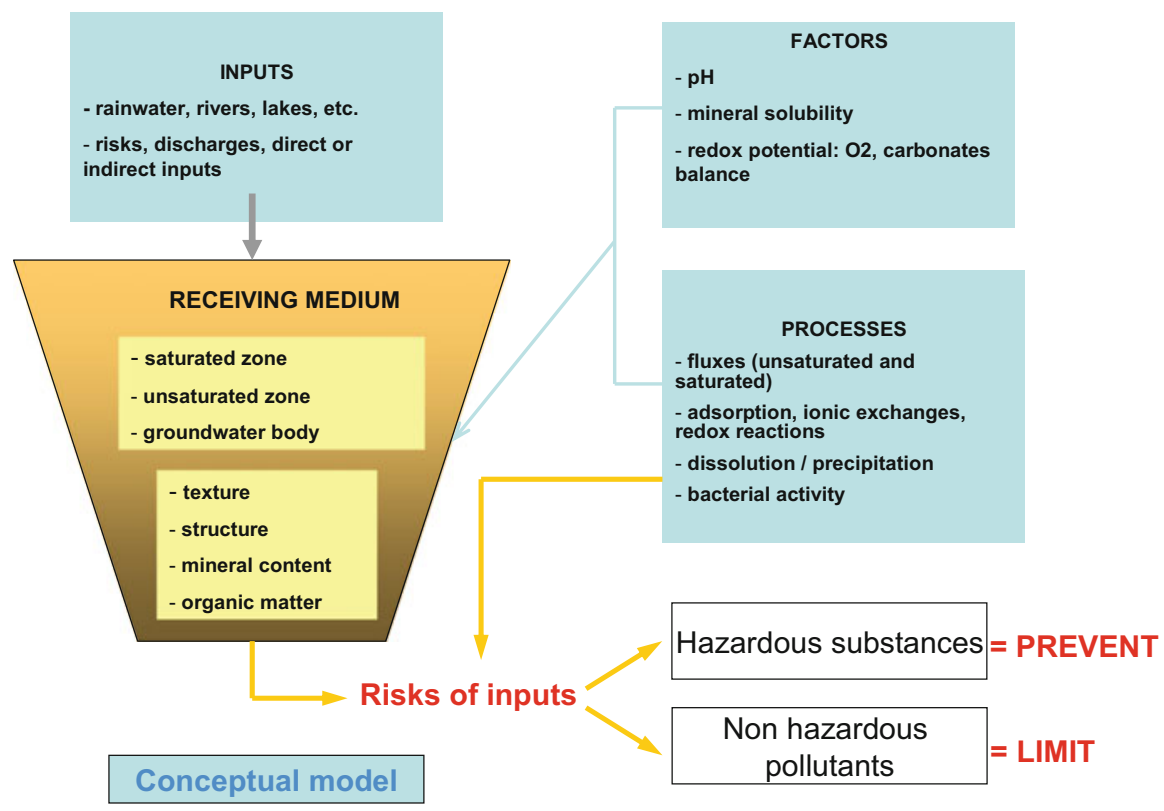

Fig. 8.2 The "Prevent and Limit" provisions linked to an evaluation of risks of inputs (and of the understanding of the groundwater system)

\subsection{An Example from Michigan, USA: A State Level Approach}

In contrast to an EU-scale approach, this section describes a statewide innovative management model for considering the ecological impact of groundwater and surface water withdrawals. The approach is notable for its focus on science-based tools and involvement from a range of stakeholders in the State of Michigan. The reader is directed to Steinman et al. (2011), and citations contained therein, for detailed coverage of the historical aspects and processes employed; Hamilton and Seelbach (2011) provide a comprehensive description of the withdrawal assessment process and Internet screen tool.

Groundwater management within the Michigan regulatory context derives directly from a series of governing laws, including:

- Definition and characterisation of groundwater bodies (management units) within well-were initially defined on an international scale. In 2001 and 2005, the governors and premiers of all United State Great Lakes states and Canadian provinces, respectively, committed to developing a progressive water management system to protect the waters of the Great Lakes basin. In 2005, the governors and premiers signed the "Annex 2001 Implementing Agreements" which banned diversions of water outside the Great Lakes (with limited 
exceptions). The Annex consisted of a good faith agreement between all parties, and a binding Compact among the eight US Great Lakes States. As a result, Great Lakes region has an overarching common regulatory framework, which is enforceable against the interstate movement of Great Lakes water due to its being ratified by the federal government;

- The Compact allows flexibility in each state's approach to implementation. A common, resource-based conservation standard applies to new or increased large-quantity (over 265 litres per minute (100,000 gallons per day)) water withdrawals from the Great Lakes basin. The intent of the standard is to avoid significant adverse individual or cumulative impacts on the quantity and quality of the waters and water-dependent natural resources of the Great Lakes basin;

- The states and provinces are also required to: establish programs to manage and regulate new or increased withdrawals; implement mechanisms for decision making and dispute resolution; develop an assessment approach for individual and cumulative impacts of water withdrawals; and augment scientific information in the Great Lakes basin and the impacts of the withdrawals on the ecosystems;

- To execute their responsibilities of the 2001 Annex agreement, the Michigan legislature passed Public Act 148 in 2003. The law's language formed the Groundwater Conservation Advisory Council and placed it within the Michigan Department of Environmental Quality (MDEQ), and explicitly denoted that its membership would consist of ten voting members from water using stakeholders and three non-voting (state agency) members. Public Act 148 also mandated a groundwater inventory and mapping effort.

- Initially, the 2003 Council was charged to: (1) study statewide sustainability and assess the need for additional oversight over groundwater withdrawals; (2) assess the state's implementation and statutory conformance with Annex 2001 requirements; and (3) assess the implementation and results from a dispute resolution program. The Council was given 2.5 years to submit a final report to the Michigan Legislature.

- After receiving the Council's final report, the Michigan Legislature enacted Public Act 34, legislation in 2006, legislation that for the first time regulated water withdrawals in the state and explicitly mandated that science should be used as the basis for decision making - a specific requirement of the overarching Compact. The 2006 law reconstituted the Council, which was then tasked to develop explicit criteria for judging sustainability, and to develop and design a water withdrawal assessment tool.

Criteria for Assessing Sustainability Efforts focused on development of characteristics of sustainability criteria and indicators. Criteria were defined as standards or points of reference that help in choosing indicators; they are more general and less detailed than indicators. Indicators were defined as measures that present relevant information on trends in a readily understandable way. Good indicators were defined as those that adequately represent the societal concern, be measurable, consistent, based on readily available or obtainable information, and 
comparable among various geographic regions (Steinman et al. 2011). Eleven indicators were identified (Table 8.1). Five environmental indicators focused on water quantity and quality. An indicator of the impacts of water withdrawal on groundwater-dependent biota was not developed because the state of the science was not sufficient to adequately relate the effect of withdrawals on these biota. Consensus was reached on three general economic indicators (Table 8.1), after considerable debate; three social sector indicators were identified (Table 8.1) that focused on public education, conservation and restricted groundwater access.

Development of a Water Withdrawal Assessment Tool The purpose of the water withdrawal assessment tool is to assist a large quantity user (threshold of 265 litres per minute/100,000 gallons per day defined using the Great Lakes Compact language) or the state discern if a proposed withdrawal is likely to cause an Adverse Resource Impact (ARI). An ARI is characterized in terms of an ecological functional impairment and defined by whether or not a water withdrawal impairs the ability of a surface-water body to support characteristic fish populations. Thus, fishery health was used as a biological proxy for overall stream functional integrity. The final water withdrawal assessment process provides outputs on two levels: (1) a screening tool, that is designed to 'screen in' (that is, to say yes to) those proposed withdrawals that are highly certain not to cause an ARI; and (2) for those withdrawals not initially 'screened in'. The applicant has a choice: they may either change the size, location, or depth of the proposed withdrawal in order to attain a 'screen in' decision or, if their application cannot pass using the tool, they may request the MDEQ to undertake a site-specific review. The applicant can provide site-specific measurements to assist with this review, but the expectation was that the review can be performed using readily available information.

The Internet-based (on-line) water withdrawal assessment tool comprises three models linked through a GIS. The models use information about streamflow, groundwater withdrawal and existing fish communities, with detailed resolution that allows site specific assessments of stream segments across Michigan. The streamflow model is a regression model that describes how much flow is in Michigan streams. An index flow is calculated from online data obtained from 147 established stream gages. Index flow is defined as the median flow for the summer month with lowest flow at a site. Summer months (usually August or September) were used because they commonly have the lowest flows and warmest temperatures, which result in the greatest stress to fisheries. A subsequent analytical withdrawal model estimates how much a proposed groundwater withdrawal will reduce streamflow in streams near the proposed pumping location. This model takes into account the amount and duration of pumping, well depth distance of well from stream, and aquifer properties (Reeves et al. 2009). The withdrawal assessment tool can also account for direct surface water withdrawal by subtracting it from the amount of available water.

The most critical component is the third model, a fish community statistical model that relates reduced streamflow to fish populations. This model leverages a 
Table 8.1 Recommended groundwater sustainability indicators and their associated measurement and criteria for the environmental economic and social sectors (Taken from Steinman et al. 2011)

\begin{tabular}{|c|c|c|}
\hline Indicator & Measurement & Criteria \\
\hline \multicolumn{3}{|l|}{ Environmental sector } \\
\hline $\begin{array}{l}\text { 1. Groundwater } \\
\text { contribution to stream } \\
\text { baseflow }\end{array}$ & $\begin{array}{l}\text { 1-1. Change in } \\
\text { groundwater contribution } \\
\text { over time }\end{array}$ & $\begin{array}{l}\text { 1-1. Adequate groundwater discharge to } \\
\text { maintain natural flow and temperature } \\
\text { regimes }\end{array}$ \\
\hline $\begin{array}{l}\text { 2. Groundwater } \\
\text { withdrawals }\end{array}$ & $\begin{array}{l}2-1 . \text { Volume of water use } \\
\text { by sector }\end{array}$ & $\begin{array}{l}\text { 2-1. Efficient use to maintain adequate } \\
\text { supply for public and private needs }\end{array}$ \\
\hline \multirow[t]{2}{*}{ 3. Land use/land cover } & $\begin{array}{l}\text { 3-1 Percentage natural } \\
\text { land use/land cover }\end{array}$ & 3-1. Increase \\
\hline & $\begin{array}{l}\text { 3-2. Percentage } \\
\text { impervious surface }\end{array}$ & $\begin{array}{l}\text { 3-2. Decrease below reference } \\
\text { impairment thresholds }\end{array}$ \\
\hline $\begin{array}{l}\text { 4. Groundwater } \\
\text { contamination }\end{array}$ & $\begin{array}{l}\text { 4-1. Number of at-risk } \\
\text { sites }\end{array}$ & 4-1. Decrease \\
\hline $\begin{array}{l}\text { 5. Groundwater- } \\
\text { dependent natural } \\
\text { communities }\end{array}$ & Not developed & Not developed \\
\hline \multicolumn{3}{|l|}{ Economic sector } \\
\hline $\begin{array}{l}\text { 6. Cost of groundwater } \\
\text { by relevant economic } \\
\text { sector }\end{array}$ & Not developed & Not developed \\
\hline \multirow[t]{2}{*}{$\begin{array}{l}\text { 7. Groundwater } \\
\text { dependent commerce }\end{array}$} & $\begin{array}{l}\text { 7-1. Product-revenue per } \\
\text { unit groundwater per } \\
\text { sector }\end{array}$ & 7-1. Increase \\
\hline & $\begin{array}{l}\text { 7-2. Efficiency of } \\
\text { groundwater use per } \\
\text { sector }\end{array}$ & 7-2. Increase \\
\hline \multirow[t]{2}{*}{$\begin{array}{l}\text { 8. Water usage from } \\
\text { alternative sources }\end{array}$} & $\begin{array}{l}\text { 8-1. Gallons of water } \\
\text { recycled }\end{array}$ & 8-1. Increase \\
\hline & $\begin{array}{l}\text { 8-2. Gallons of water } \\
\text { used from collection of } \\
\text { stormwater }\end{array}$ & 8-2. Increase \\
\hline \multicolumn{3}{|l|}{ Social sector } \\
\hline \multirow[t]{3}{*}{ 9. Public education } & $\begin{array}{l}\text { 9-1. Public knowledge of } \\
\text { groundwater resources }\end{array}$ & 9-1. Increase \\
\hline & $\begin{array}{l}\text { 9-2. Water resource } \\
\text { education }\end{array}$ & 9-2. Increase \\
\hline & $\begin{array}{l}\text { 9-3. Local government } \\
\text { training }\end{array}$ & 9-3. Increase \\
\hline \multirow[t]{2}{*}{ 10. Conservation } & $\begin{array}{l}\text { 10-1 Public water } \\
\text { systems using } \\
\text { groundwater }\end{array}$ & $\begin{array}{l}10-1 . \text { Efficient use to maintain adequate } \\
\text { supply for public and private needs }\end{array}$ \\
\hline & $\begin{array}{l}\text { 10-2 Water utilization by } \\
\text { sector }\end{array}$ & 10-2. Unspecified \\
\hline \multirow[t]{3}{*}{$\begin{array}{l}\text { 11. Restricted } \\
\text { groundwater access }\end{array}$} & $\begin{array}{l}\text { 11-1. Use restrictions due } \\
\text { to contamination }\end{array}$ & 11-1. Decrease \\
\hline & $\begin{array}{l}\text { 11-2. Adverse Resource } \\
\text { Impacts (ARIs) }\end{array}$ & 11-2. Decrease \\
\hline & 11-3. Water use conflicts & 11-3. Decrease \\
\hline
\end{tabular}




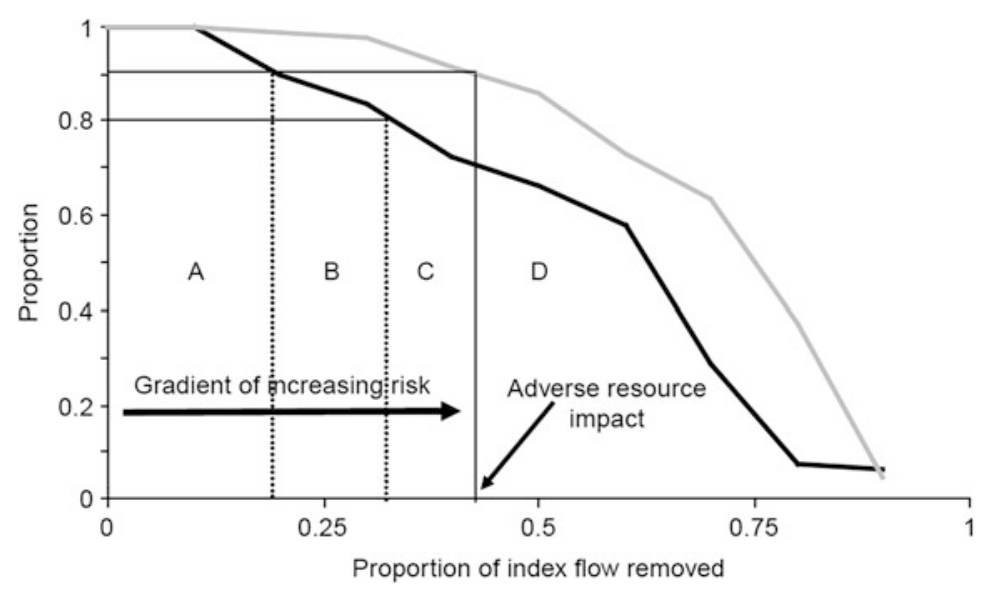

Fig. 8.3 Hypothetical example showing four policy zones (A-D), demarcated by increasing levels of index flow removal and functional response of fish populations (proportion of populations). The black curve represents the response of those fish whose needs are best suited to the stream temperature and flows. The gray line represents the response of more tolerant fish that require similar stream temperature and flows but are not as tied to the conditions as those represented by the dark line (From Steinman et al. 2011, used with permission)

large Michigan Department of Natural Resource's dataset of fish abundance at around 1700 stream locations in Michigan. Fish abundance is related to 11 river classes in Michigan, based on temperature type (cold, cold-transitional, cool, and warm) and size (large rivers, small rivers, and streams). This model estimates, for each of the 11 stream classes, the change in fish populations caused by reducing streamflow by using characteristic response curves.

Two curves were generated for each of the 11 stream classes in Michigan; these curves show how fish population responds as flow is incrementally reduced (Fig. 8.3). The leftmost curve shows the response of thriving species (fish best suited for stream conditions) and a rightmost curve that shows abundance reductions of other fish that more general and less dependent on the stream condition environmental niche (Zorn et al. 2008). This curve was divided using stakeholder and scientist input, and resulted in three vertical lines and four corresponding zones (A-D-Fig. 8.3). The far left vertical line (demarcating zones $\mathrm{A}$ and $\mathrm{B}$ ) showed the theoretical edge of minor impact, whereas the far right vertical line showed the theoretical start of an ARI (Fig. 8.3). That is, Zone A represents minimal measurable impact on fish populations, but as more flow is removed, there is a gradient of increasing risk to the point where notable replacement of fish species occurs, thereby constituting an ARI (Fig. 8.3).

According to 2006 Public Act 34, a person considering a new or increased large quantity withdrawal is not allowed to cause an ARI. A proposed user may either start the application process on-line by using the screening tool or they may work directly with MDEQ staff to conduct a site-specific analysis (Fig. 8.4). The screening tool estimates the amount of flow reduction for the appropriate stream segment 


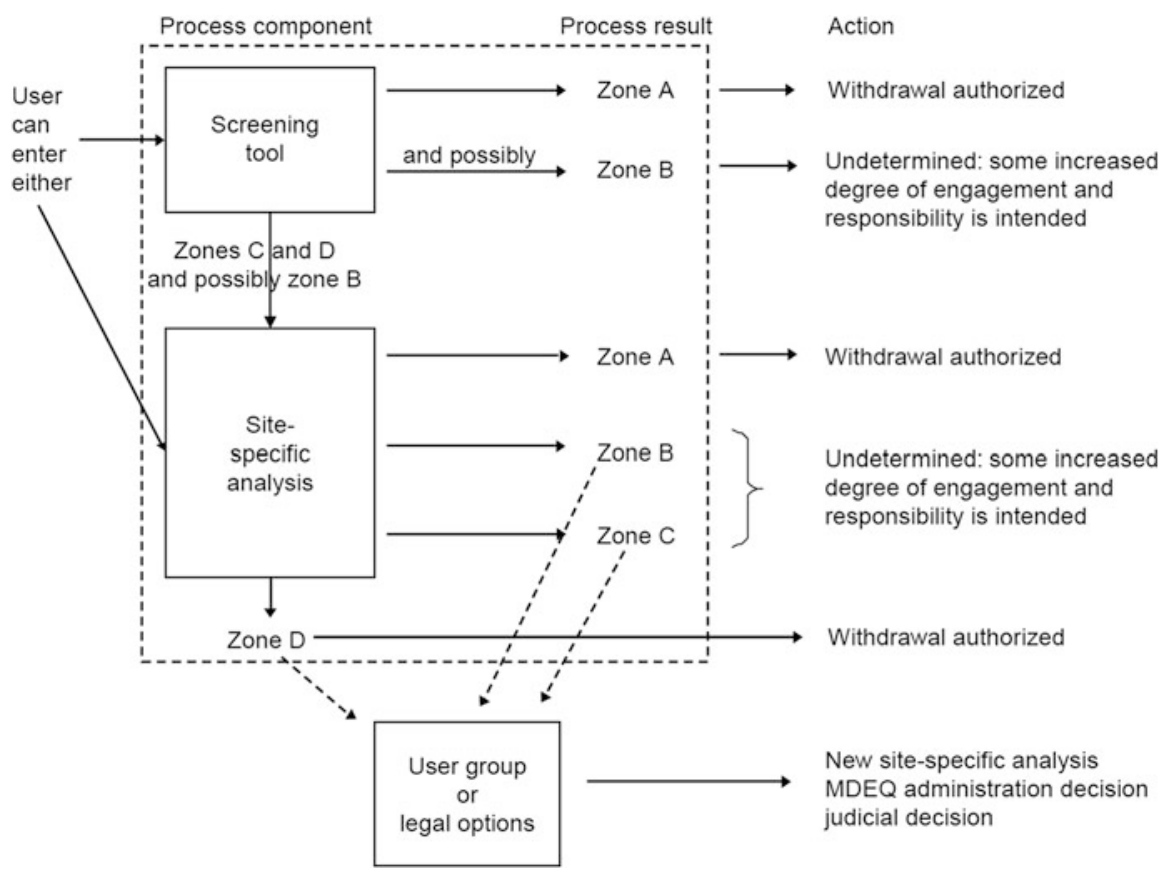

Fig. 8.4 Decision-making system associated with the water withdrawal process. Zones listed under process results correspond to Fig. 8.3 (From Steinman et al. 2011, used with permission)

and makes one of two determinations for the proposed withdrawal: (1) that it is not likely to cause an ARI and is authorized; or (2) that there is too much uncertainty in the outcome to determine whether or not the withdrawal would be likely to cause an ARI, and therefore the withdrawal may not proceed without a site-specific review. For a Zone A determination (ARI not likely; Figs. 8.3 and 8.4), the user would simply register the proposed withdrawal with MDEQ and receive authorization to proceed. For Zones B and C determination (ARI possible; Figs. 8.3 and 8.4), the applicant can modify the proposal and try the screening tool again or they can request the MDEQ to conduct a site-specific analysis of the withdrawal, with the expectation that a site-specific analysis will have less uncertainty associated with the withdrawal estimate than the screening tool. As of 9 July 2009, use of the screening tool is required by individuals proposing a large quantity withdrawal (265 litres per minute/100,000 gallons per day) from the groundwaters of Michigan. However, the Council recognized that the water withdrawal assessment tool is a work in progress (Steinman et al. 2011), specifically with the proposed the boundaries of Zones A and D (Fig. 8.3). They suggested that these were the starting points for further policy discussion, and recognizing that the social values of affected constituencies ultimately would influence the location of the boundaries. Indeed, the 2008 implementing legislation contained significant negotiated changes 
in the location of the Zone A and D lines for most of the 11 stream classifications (Steinman et al. 2011).

A new group, the Michigan Water Resources Conservation Advisory Council, was created as part of legislation passed in 2008. This group extends the earlier work but has a broader membership, and is charged with evaluating all water resources in the state, not just groundwater. Specifically, the new council is charged with: (1) evaluation of the water withdrawal assessment tool; (2) evaluation of the overall water withdrawal assessment process; (3) recommendations for inclusion of Great Lakes, inland lakes, and other waters in the process; (4) examining any potential legal conflicts within the process; and (5) recommendations for a new state water conservation and efficiency program (Steinman et al. 2011).

\subsection{The Australian Approach}

In comparison to the EU and US examples, this section reviews the background, past and current issues in groundwater regulation and integrated water planning for Australia.

\subsubsection{Early Approach}

In Australia water management has been dominated during most of the first 200 years of settlement by providing sufficient water for the growing population, agriculture and industry, hence aiming at increasing the exploitation of water. As Australia has high rainfall variability and is the driest continent on earth, exploitation of water resources has always been strongly linked to irrigation as it is the biggest water user (CSIRO 2011).

Irrigation started in 1886 in Mildura on the banks of the Murray River drawing on expertise from irrigation schemes in California to Victoria. Ownership of water and the rights to water use was setup according the model established by the Victorian Irrigation Act of 1886 and translated into State legislative arrangements. The legislation followed the principle that all streams were public property, and vested in the State or Crown the right to the use and flow, and to the control of water in any watercourse. Ownership and right of use of groundwater arose subsequently to that of surface water and hence the property in and the rights to the use, flow and control of all groundwater was vested in the Crown since 1910 by the different States, starting with Queensland (Acworth et al. 2009).

\subsubsection{The Murray-Darling Basin}

The Murray-Darling Basin covers more than 1 million $\mathrm{km}^{2}$ and spans most of the states of New South Wales, Victoria, and the Australian Capital Territory, and parts of the states of Queensland and South Australia. Agriculturally it is essential for the 
food production of Australia, while the management of irrigation in the basin has a long history and is still a politically sensitive issue. A drought period (1895-1902) and the Federation of Australia (1901) drove the government to start managing and regulating the Murray River system. The upstream states, Victoria and New South Wales, favoured the riparian doctrine, under which landowners are free to take water from streams flowing through their property. South Australia relied on agreements in the new Constitution on navigation along the Murray River to preserve flows in the South Australian section of the river (Wikipedia Contributors 2013).

The River Murray Waters Agreement (1915) did set out how flow and control is shared between New South Wales and Victoria and how South Australia is guaranteed of a minimum quantity of water or "entitlement". The agreement was also the starting point for construction of dams, weirs and locks on the main stream of the Murray to be managed by the River Murray Commission, which was established in 1917. As water is a state authority this agreement was an early example of federal cooperation on water, although limited to the management of water for irrigation and navigation (Wikipedia Contributors 2013).

As over the decades environmental problems due to overallocation of water for irrigation become seriously felt, the need for more coordination at the Basin level became evident. Updated and new versions of the Murray-Darling Basin Agreement were signed in respectively 1987 and 1992. The stated purpose of the MurrayDarling Basin Agreement was 'to promote and coordinate effective planning and management for the equitable, efficient and sustainable use of the water, land and other environmental resources of the Murray-Darling Basin'. To support the new Agreement, institutions at the political, bureaucratic and community levels were established, respectively (Wikipedia Contributors 2013):

- Murray-Darling Basin Ministerial Council;

- Murray-Darling Basin Commission; and

- Community Advisory Committee.

In 2012 finally after long negotiations the different Murray-Darling Basin states agreed on a new Murray-Darling Basin plan with as main result the promise to return 3200 gigalitres of environmental flows to the basin system annually, which is regarded essential to restore the strongly deteriorated health of the river's floodplains, and important large RAMSAR and other wetlands. The basin plan foresees setting up strategies for environmental watering, trading and sustainable diversion limits. The plan further encompasses state water resources planning, revision and review steps of the plan (Fig. 8.5).

\subsubsection{Groundwater Use}

In 2013 the total water consumption in Australia is estimated to be about 15,000 GL per year. Approximately one third of this amount comes from groundwater, with 


\section{BASIN PLAN implementation steps}

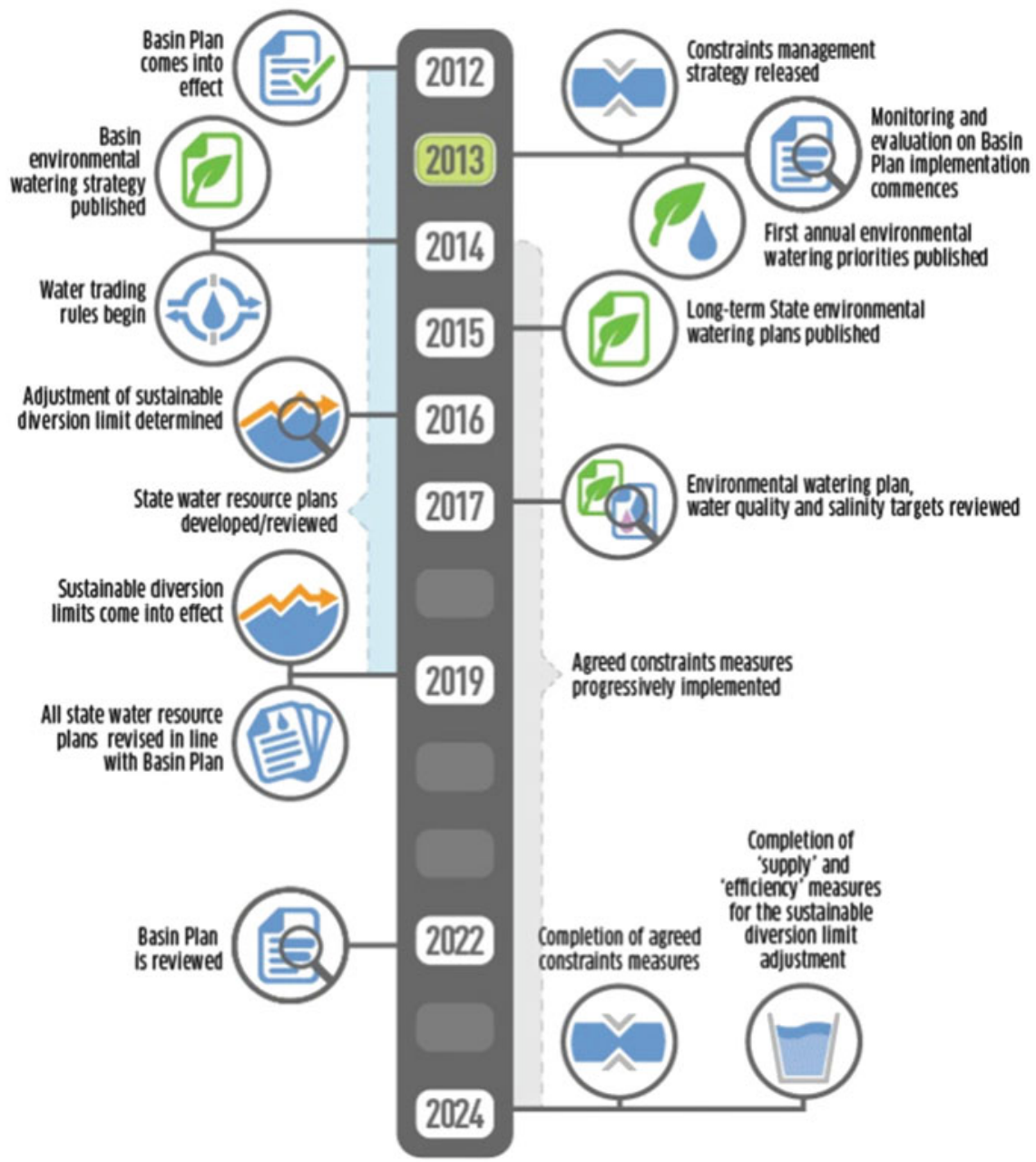

Fig. 8.5 Murray-Darling Basin Plan implementation steps (Murray-Darling Basin Authority 2013)

use doubling between 1983/1984 and 1996/1997 (AWRA 2000). These values have a high uncertainty as only a small fraction of abstraction wells are metered. The highest use of groundwater is in the Murray-Darling Basin, where over $1700 \mathrm{GL}$ of groundwater is abstracted annually in support of irrigated agriculture (NCGRT 2013; Murray-Darling Basin Authority 2010; CSIRO 2008).

The highest ratios of groundwater use to sustainable yield are found in Queensland (38\%), South Australia (33\%), New South Wales (26\%) and Western Australia (20\%). However, these statistics are misleading as they suggest scope for 
more groundwater extractions. While that is true in some areas, many major aquifers have been exploited up to or exceeding the sustainable yield, especially the Great Artesian Basin and alluvial aquifers of the Murray-Darling Basin. The lack of resource management and monitoring of groundwater systems have led to this overallocation and extraction, which was worsened by too little metering of groundwater extractions, provision of free or under-priced groundwater and not recognizing the importance of groundwater-surface water interaction (NWC 2013).

\subsubsection{National Level Policy}

\subsubsection{The National Water Initiative}

In 2004 a National Water Initiative was started as a consequence of the fact that the Murray-Darling Basin Agreement did not result in significant improvement in the environmental conditions in the basin as well as because of the growing number of other water policy issues elsewhere in Australia (Wikipedia Contributors 2013). As part of the National Water Initiative a National Water Commission was established through an intergovernmental agreement (Council of Australian Governments). The Commission provides independent and public advice to the Council of Australian Governments and the Australian Government by assessing, auditing and monitoring water reform progress. The main policy agreement is the National Water Initiative, Australia's enduring blueprint for water reform. The National Water Initiative agreement included objectives, outcomes and agreed commitments to (NWC 2013):

- prepare water plans with provision for the environment

- deal with overallocated or stressed water systems

- introduce registers of water rights and standards for water accounting

- expand the trade in water

- improve pricing for water storage and delivery

- meet and manage urban water demands.

Full implementation of the National Water Initiative aims to deliver (NWC 2013):

- effective water planning: transparent and statutory-based water planning that deals with key issues such as the natural variability of water systems, major water interception activities, the interaction between surface water and groundwater systems, and the provision of water to achieve specific environmental outcomes.

- clear, nationally compatible and secure water access entitlements: providing more confidence for those investing in the water industry through more secure 
water entitlements; better and more compatible registry arrangements; better monitoring, reporting and accounting; and improved public access to information.

- conjunctive management of surface water and groundwater resources: so that the connectivity between the two is recognised, and connected systems are managed in an integrated manner.

- resolution of overallocation and overuse: returning overallocated systems to sustainable levels of extraction as quickly as possible.

- clear assignment of the risks associated with changes in future water availability: ensuring that the risks arising from reductions in the pool of water available for consumptive use are shared between governments and water users according to an agreed framework, to provide investors and entitlement holders with certainty about how changes will be dealt with.

- effective water accounting: providing information on how much water there is, where it is, who has control of it, who is using it, and what it is being used for in order to support confidence about the amount of water being delivered, traded, extracted and managed for environmental and other public benefits.

- open water markets: removing artificial barriers to trading in water entitlements and allocations, bringing about more productive water use and enabling more cost-effective and flexible recovery of water to achieve economic, social and environmental objectives.

- effective structural adjustment ensuring that water policy, planning and management are facilitating and expediting adjustment, rather than impeding it.

Under the National Water Commission Act, the Commission has to report to the Council of Australian Governments on progress towards National Water Initiative objectives and outcomes. Reports were delivered in 2007, 2009 and 2011 and will further be delivered on a triennial basis (NWC 2013).

\subsubsection{National Groundwater Action Plan}

A National Groundwater Action Plan was initiated by the National Water Commission in 2007 as a consequence of the millennium drought (1997-2009). It had three elements (McKay 2012; NWC 2013):

- The National Groundwater Assessment Initiative: investigations to help overcome critical groundwater knowledge gaps.

- The National Centre for Groundwater Research and Training: a joint venture between the National Water Commission and Australian Research Council to build capacity in groundwater knowledge.

- A knowledge and capacity-building component: improvements in understanding and sustainable management of groundwater resources. 
Within the National Groundwater Action Plan groundwater reforms and investments were foreseen in eight priority themes (McKay 2012; NWC 2013):

- Harmonization of groundwater definitions and standards, and improved governance and management practices.

- Northern Australia Groundwater Stocktake.

- National assessment of sites suitable for managed aquifer recharge and recovery.

- Vulnerability assessment of groundwater-dependent ecosystems.

- Investigation of groundwater-surface water interconnectivity.

- Strategic aquifer characterization to quantify sustainable yields.

- National review of groundwater potential for deep fresh, saline and brackish waters.

- Managing risks to groundwater quality.

\subsubsection{Implementation of Policy at State and Local Levels}

As the different States are also responsible for the management of groundwater each bases it on their own legislation and regulates it via water management agencies, department of water or natural resources management agencies. The formulation of Natural Resource Management legislation has brought the integrated management of natural resources under one management portfolio in some States (Acworth et al. 2009).

Groundwater in Australia is governed by state policies mostly implemented through local area plans. However, a considerable part of Australia is still managed at statewide level because of either the low level of development or because of the general poor quality of the groundwater resources. Allocation of groundwater occurs via a system of renewable water access entitlements. Allocation planning requires assessment of sustainability, which is defined by the National Water Initiative as 'the level of water extraction from a particular system that, if exceeded, would compromise key environmental assets, or ecosystem functions and the productive base of the resource'. A range of methods is used to estimate the sustainable yield often reflecting the state of the knowledge of particular hydrogeological systems (NLWRA 2001; Acworth et al. 2009; NCGRT 2013). Options for optimization of use are (Acworth et al. 2009):

- Fixed water allocations, where licences can use up to a fixed amount. Penalties can be applied if use exceeds allocations.

- Announced allocations, where allocations are varied, usually from $75 \%$ to $125 \%$ of the fixed allocation, depending on the volume in storage at the start of the main demand period.

- A system of advanced draws, where licensees can "borrow" against next year's allocation, with that year's allocation being reduced (a gamble on next year's wet season). 
- A system of moving averages, whereby use is averaged with the two (or some other agreed number) preceding years, in order to average water use with the varying seasons.

- Temporary trading, where unused allocations can be transferred to other users, usually subject to some conditions. These transfers are usually private transactions, often financial, which must be sanctioned by the managing authorities.

- Permanent trading, where allocations can be sold permanently to others.

- Conjunctive allocations where groundwater and surface water allocations are tied.

\subsubsection{Groundwater Quality}

In terms of water quality the joint Australian-New Zealand National Water Quality Management Strategy of 1994 sets out the management process to achieve sustainable use of water resources, by protecting and enhancing their quality, while maintaining economic and social development (NWQMS 1994). As part of this National Water Quality Management Strategy the groundwater protection guideline details the principles for groundwater protection, which received comparably little attention over the decades. The protection framework involves the identification of specific beneficial uses and values for every major aquifer. Protection strategies include development of vulnerability maps, aquifer classification systems and wellhead protection plans, land-use planning measures and environmental management of modern waste management problems. All of these involve monitoring. Nearly all protection strategies will rely on government intervention, a public planning process and should be backed by community support (NWQMS 1995).

\subsubsection{Challenging Contemporary Groundwater Management Issues}

Australia faces currently and in the coming decades a number of highly challenging groundwater management issues. A robust policy framework is in place to address these, but it is likely that further adaptation and development of (ground)water policies will be required. Such issues include (Acworth et al. 2009; Tan et al. 2012; NCGRT 2013).

- Unsustainable groundwater extractions beyond natural recharge rates in some aquifer systems.

- As more than $85 \%$ of the Australian population lives in coastal areas $(<50 \mathrm{~km})$ salt-water intrusion into coastal aquifers is a real threat for some locations (Ivkovic et al. 2012). 
- Rising groundwater levels and resulting water logging/salinisation of soils due to irrigation is an on-going issue and needs sustained research and groundwater management.

- The use of water of marginal quality for irrigation and recycling causing salinity build-up in the underlying groundwater.

- Groundwater use by mining operations and especially the development of coal seam gas exploitation can introduce new groundwater related problems, which require groundwater research, monitoring and development of new management policies.

- Groundwater Dependent Ecosystems (GDEs) contribute significantly to social, economic, biodiversity and spiritual values (Murray et al. 2003). More knowledge of the specific requirements of GDEs is needed for effective management.

- The application of Managed Aquifer Recharge (MAR) is strongly increasing and has a number of benefits in terms of water management. However, as generally recycled or storm water is used for the recharge any risks of deteriorating water quality and health has to be managed. MAR guidelines have been established (NRMMC 2009).

- Analysis of the climate over the last 80 years shows a warming over most of Australia, increasing rainfall over northern, central and north-western Australia and decreasing rainfall in eastern, south-eastern and south-western Australia. As recharge is more variable than rainfall the effect of climate change on groundwater supplies will be more pronounced in areas of low recharge (Barron et al. 2011). Climate change will increase demand for water for irrigation, cities, wetlands, etc., intensifying the water scarcity.

- The value of water for indigenous Australians for culture, identity, as well as livelihood are poorly understood (CSIRO 2011; Jackson et al. 2012; Liedloff et al. 2013).

- As clearly groundwater management had in Australia a strong focus on quantitative aspects, further development of integrated quantitative-qualitative-ecological and publicly supported policies embedded in socio-economic plans is evident for long-term management of sustainable groundwater resources.

Open Access This chapter is distributed under the terms of the Creative Commons AttributionNoncommercial 2.5 License (http://creativecommons.org/licenses/by-nc/2.5/) which permits any noncommercial use, distribution, and reproduction in any medium, provided the original author(s) and source are credited.

The images or other third party material in this chapter are included in the work's Creative Commons license, unless indicated otherwise in the credit line; if such material is not included in the work's Creative Commons license and the respective action is not permitted by statutory regulation, users will need to obtain permission from the license holder to duplicate, adapt or reproduce the material. 


\section{References}

Acworth I, Hazel C, Laws T, Lawrence C (eds) (2009) Australian groundwater school, the notes. National Centre for Groundwater Research and Training, Adelaide

AWRA (2000) Australian water resources assessment 2000. http://www.anra.gov.au/topics/water/ pubs/national/water_use.html

Barron OV, Crosbie RS, Charles SP, Dawes WR, Ali R, Evans WR, Cresswell R, Pollock D, Hodgson G, Currie D, Mpelasoka PT, Aryal S, Donn M, Wurcker B (2011) Climate change impact on groundwater resources in Australia, vol 67, Waterlines report series. National Water Commission, Canberra

Burke JJ, Moench MH (2000) Groundwater and society: resources, tensions and opportunities. United Nations, New York. ISBN 92-1-104485-5

CSIRO (2008) Water availability in the Murray-Darling Basin a report to the Australian Government from the CSIRO Murray-Darling Basin Sustainable Yields project. CSIRO, Clayton South, $67 \mathrm{pp}$

CSIRO (2011) In: Prosser IP (ed) Water: science and solutions for Australia. CSIRO Publishing, Collingwood

European Commission (2006) Directive of the European Parliament and the Council on the protection of groundwater against pollution and deterioration. J Eur Comm L372:19

Hamilton DA, Seelbach PW (2011) Michigan's water withdrawal assessment process and internet screening tool. Michigan Department of Natural Resources, Fisheries special report 55, Lansing, $37 \mathrm{p}$

Hunt RJ, Anderson MP, Kelson VA (1998) Improving a complex finite difference groundwaterflow model through the use of an analytic element screening model. Ground Water 36 (6):1011-1017. doi:10.1111/j.1745-6584.1998.tb02108.x

Ivkovic KM, Marshall SM, Morgan LK, Werner AD, Carey H, Cook S, Sundaram B, Norman R, Wallace L, Caruana L, Dixon-Jain P, Simon D (2012) National-scale vulnerability assessment of seawater intrusion: summary report. Waterlines report no 85. National Water Commission, Canberra

Jackson S, Tan P-L, Mooney C, Hoverman S, White I (2012) Principles and guidelines for good practice in Indigenous engagement in water planning. J Hydrol 474:57-65

Liedloff AC, Woodward EL, Harrington GA, Jackson S (2013) Integrating indigenous ecological and scientific hydro-geological knowledge using a Bayesian network in the context of water resource development. J Hydrol 499:177-187

McKay J (2012) Groundwater management: looking to the future so there is a future. Water Int 37 (7):721-726

Mostert E, Van Beek E, Bouman NWM, Hey E, Savenije HHG, Thissen WAH (1999) River basin management and planning, proceedings of the international workshop on river basin management, The Hague, 27-29 Oct 1999, IHP-V, Technical Documents in Hydrology No 31, UNESCO, pp 24-55

Murray BR, Zeppel MJB, Hose GC, Eamus D (2003) Groundwater-dependent ecosystems in Australia: it's more than just water for rivers. Ecol Manag Restor 4(2):110-113

Murray-Darling Basin Authority (2010) Guide to the proposed basin plan: overview MurrayDarling Basin authority, Canberra. Available from http://www.mdba.gov.au

Murray-Darling Basin Authority (2013) Murray-Darling basin authority, Canberra. Website http:// www.mdba.gov.au/. Accessed 8 Sept 2013

NCGRT (2013) Groundwater in Australia. National Centre for Groundwater Research and Training, Adelaide

NLWRA (2001) National land and water resources audit, Australian water resources assessment 2000. Commonwealth of Australia, Canberra

NRMMC (2009) Natural resource management ministerial council, Environmental Protection and Heritage Council (EPHC) \& National Health and Medical Research Council (NHMRC) Australian guidelines for water recycling, managing health and environmental risks (phase 
2) - managed aquifer recharge, national water quality management strategy. Available at: http://www.ephc.gov.au/taxonomy/term/39

NWC (2013) National Water Commission. Available from http://www.nwc.gov.au/. Accessed 6 Sept 2013

NWQMS (1994) National Water Quality Management Strategy, document 1: water quality management-an outline of the policies. Available from http://www.environment.gov.au/ water/publications/quality/index.html

NWQMS (1995) National Water Quality Management Strategy, document 8: guidelines for groundwater protection. Available from http://www.environment.gov.au/water/publications/ quality/index.html

Quevauviller P (ed) (2008) Groundwater science and policy-an international overview. RSC Publishing, Cambridge, p 754. ISBN 978-085404-294-4

Reeves HW, Hamilton DA, Seelbach PW, Asher AJ (2009) Groundwater-withdrawal component of the Michigan water-withdrawal screening tool. United States Geological Survey Scientific Investigations report 2009-5003

Steinman AD, Nicholas JR, Seelbach PW, Allan JW, Ruswick F (2011) Science as a fundamental framework for shaping policy discussions regarding the use of groundwater in the State of Michigan: a case study. Water Policy 13:69-86

Tan P-L, Bowmer KH, Mackenzie J (2012) Deliberative tools for meeting the challenges of water planning in Australia. J Hydrol 474:2-10

Wikipedia Contributors (2013) Irrigation in Australia Wikipedia, The Free Encyclopaedia. http:// en.wikipedia.org/w/index.php?title=Irrigation_in_Australia\&oldid=551808498. Accessed 7 Sept 2013

Winter TC, Rosenberry DO, LaBaugh JW (2003) Where does the ground water in small watersheds come from? Ground Water 41:989-1000. doi:10.1111/j.1745-6584.2003.tb02440.x

Zorn TG, Seelbach PW, Rutherford ES, Wills TC, Cheng S, Wiley MJ (2008) A landscape-scale habitat suitability model to assess effects of flow reduction on fish assemblages in Michigan streams. Michigan Department of Natural Resources, Fisheries research report 2089, Ann Arbor 